\title{
ANALISIS KEKERINGAN METEOROLOGI MENGGUNAKAN METODE STANDARDIZED PRECIPTATION INDEX (SPI) DI DAS BEDADUNG KABUPATEN JEMBER
}

\author{
Citra Malini' ${ }^{1)}$, Gusfan Halik ${ }^{2}$, Retno Utami Agung Wiyono ${ }^{3)}$ \\ ${ }^{1,2,3)}$ Jurusan Teknik Sipil Universitas Jember \\ Email: citramalini21@gmail.com ${ }^{1)}$, gusfan.teknik@unej.ac.id ${ }^{2}$, ${\text { retnoutami@unej.ac.id }{ }^{3)}}^{\text {rat }}$ \\ Corresponden Author: gusfan.teknik@unej.ac.id \\ DOI: http://dx.doi.org/10.29103/tj.v11i2.483
}

(Received: February 2021 / Revised: March 2021 / Accepted: May 2021)

\begin{abstract}
Abstrak
Bencana kekeringan di DAS Bedadung terindikasi dengan tidak terpenuhinya kebutuhan masyarakat akan pasokan air. Kekurangan air akibat defisit curah hujan menjadi indikator kekeringan meteorologi. Penelitian ini bertujuan untuk mendapatkan nilai indeks kekeringan di DAS Bedadung kabupaten Jember. Metode Standardized Precipitation Index (SPI) digunakan untuk mendapatkan tingkat kekeringan. Tingkat kekeringan meteorologi yang dihitung tergantung jumlah curah hujan yang terukur pada alat penakar di stasiun. Hasil penelitian ini menunjukkan bahwa indeks kekeringan ekstrim terjadi pada tahun 2018 dan 2019. Nilai indeks kekeringan (SPI-6) memiliki nilai tertinggi sebesar -2,69 di stasiun Ajung dan nilai $\quad-1,13$ di stasiun Kottok. Hasil pemetaan sebaran indeks kekeringan memiliki kesesuaian dengan kondisi kekeringan observasi. Hal ini ditunjukkan dari nilai validasi sebaran kekeringan antara SPI-6 dan data kekeringan observasi dengan tingkat keandalan sebesar $82 \%$.
\end{abstract}

Kata kunci: DAS Bedadung, bencana kekeringan, indeks kekeringan meteorologi, SPI

\begin{abstract}
Drought disaster in the Bedadung watershed is indicated by the unfulfilled sociaty needs for water supply. Lack of water due to deficit in rainfall is an indicator of meteorological drought. This study aims to obtain the drought index value in the Bedadung watershed, Jember district. The Standardized Precipitation Index (SPI) method is used to obtain the drought saverity index. The meteorological drought index depends on the amount of rainfall observed on the rainfall gauge stations. The results of this study indicated that extreme drought index occurred in 2019. The drought index value (SPI-6) had the highest value of -2.69 at the Ajung station and a value of -1.13 at the Kottok station. The results of the mapping of the distribution of the drought index are suitable with drought existing conditions. This is indicated by the validation value of the drought distribution between SPI-6 and the observed drought data with a reliability level of $82 \%$.
\end{abstract}

Keywords: Bedadung watershed, drought disaster, meteorological drought index, SPI

Analisis Kekeringan Meteorologi Menggunakan Metode Standardized Preciptation Index (SPI) di Das Bedadung Kabupaten Jember-Citra Malini, Gusfan Halik, Retno Utami Agung Wiyono 


\section{Latar Belakang}

Kenaikan kontemplasi gas rumah kaca dapat menyebabkan perubahan iklim dan pemanasan global (Halik dkk., 2015). Salah satu dampaknya adalah ketersediaan air yang diperoleh dari curah hujan, apabila perubahan iklim berjalan secara tidak menentu hal ini dapat mengganggu ketersediaan sumber air di bumi (Sudarman \& As-syakur, 2018). Becana akibat terganggunya suplai air dapat menyebabkan terjadinya kekeringan atau bahkan banjir. Bencana kekeringan yang dapat digambarkan menjadi indikasi pertama kekeringan adalah kekeringan meteorologi (Adnyana dkk, 2015).

Kabupaten Jember sejak kurun waktu 23 Agustus hingga 25 November 2019 ditemukan 13 kecamatan yang terdampak kekeringan menurut data Badan Penanggulangan Bencana Daerah (BPBD). Wilayah yang terlanda paling parah yaitu di lima kecamatan yaitu Pakusari, Arjasa, Sumberjambe, Rambipuji, dan Jelbuk. Menurut (Kurniawan dkk., 2019) berdasarkan analisis dari penelitian Kurniawan kekeringan dengan menggunakan metode Palmer Drought Saverity Index pada kecamatan Patrang, Jelbuk, Arjasa dan Panti. Penelitian oleh Kurniawan terdapat saran bahwa data hujan yang digunakan adalah data yang lebih panjang untuk mendapat hasil yang akurat. Metode untuk menganalisis indeks kekeringan ada beberapa PNI, EDI, DI, RAI, CZI, MCZI, ZSI, RDI, CMI, SPI, PDSI, dan Theory of Run (Faisol dkk., 2020). Dalam penyempurnaan penelitian Kurniawan, dipilih menggunakan metode SPI dengan kala hujan lebih panjang akan memberikan representasi lebih baik dibandingkan dengan metode Palmer Drought Severity Index (PDSI) dikarenakan metode Standardized Preciptation Index (SPI) memiliki beberapa kelebihan diantaranya yaitu handal, indeks yang fleksibel, analisis hanya memerlukan data hujan, dan dapat menganalisis periode bulan basah (Saidah dkk., 2017).

Perhitungan nilai indeks kekeringan menggunakan metode SPI. Indikator kekeringan merupakan alat utama untuk membaca, meninjau, dan menilai terjadinya bahaya kekurangan air. Harga SPI negatif menandakan awal terjadinya suatu kekeringan dan nilai SPI positif menandakan telah berakhirnya kekeringan. Hasil yang diperoleh dengan metode SPI adalah kalender bulan yang terjadi kekeringan dan nilai indeksnya (Utami dkk., 2013). Hasil dari perhitungan kemudian dipetakan secara spasial untuk mengetahui sebaran kekeringan.

Validasi peta sebaran kekeringan dicocokkan dengan kekeringan di lapangan. Data yang digunakan adalah permintaan distribusi air bersih yang diminta masyarakat kepada BPBD. Penelitian ini menganalisis kekeringan dengan SPI bertujuan untuk memetakan daerah rawan bencana kekeringan di DAS Bedadung kabupaten Jember.

\section{Metode Penelitian}

Lokasi penelitian bertempat di DAS Bedadung Jember dengan 30 stasiun pengukur curah hujan. Berdasarkan studi lapangan, di beberapa desa ini memiliki resiko tinggi mengalami bencana kekeringan. Penelitian ini dilaksanakan mulai dari bulan Agustus hingga Desember 2020. Data penelitian yang dibutuhkan yaitu data sekunder curah hujan yang digunakan adalah skala waktu 30 tahun mulai dari tahun

Analisis Kekeringan Meteorologi Menggunakan Metode Standardized Preciptation Index (SPI) di Das Bedadung Kabupaten Jember - Citra Malini, Gusfan Halik, Retno Utami Agung Wiyono 
1990 sampai dengan 2019. Data curah hujan diambil dari 30 stasiun di DAS Bedadung diantaranya stasiun Sukowono, Sumber Jambe, Sembah, Arjasa, Bintoro, Kopang, Tegal Batu, Kottok, Ajung, Lojejer, Ampel, Kesilir Barat, Tamansari, Sabrang, Glundengan, Tanjungrejo, Gumelar Timur, Puger Wetan, Jambearum, Balung, Curah Malang, Rowotamtu, Klatakan, Dam Pono, Dam Karanganom, Dam Manggis, Dam Pecoro, Dam Makam, Rambipuji, dan Dam Semanggir. Data Shapefile (shp) batas DAS dan titik stasiun dibutuhkan untuk menentukan lokasi penelitian dan luas wilayah penelitian seperti pada gambar 1 . Shp batas DAS dan shp titik stasiun hujan digunakan untuk pembuatan peta persebaran kekeringan. Data lapangan untuk validasi yang digunakan yaitu jumlah distribusi air bersih dan jumlah keluarga terdampak kekeringan yang diperoleh dari BPBD kabupaten Jember.

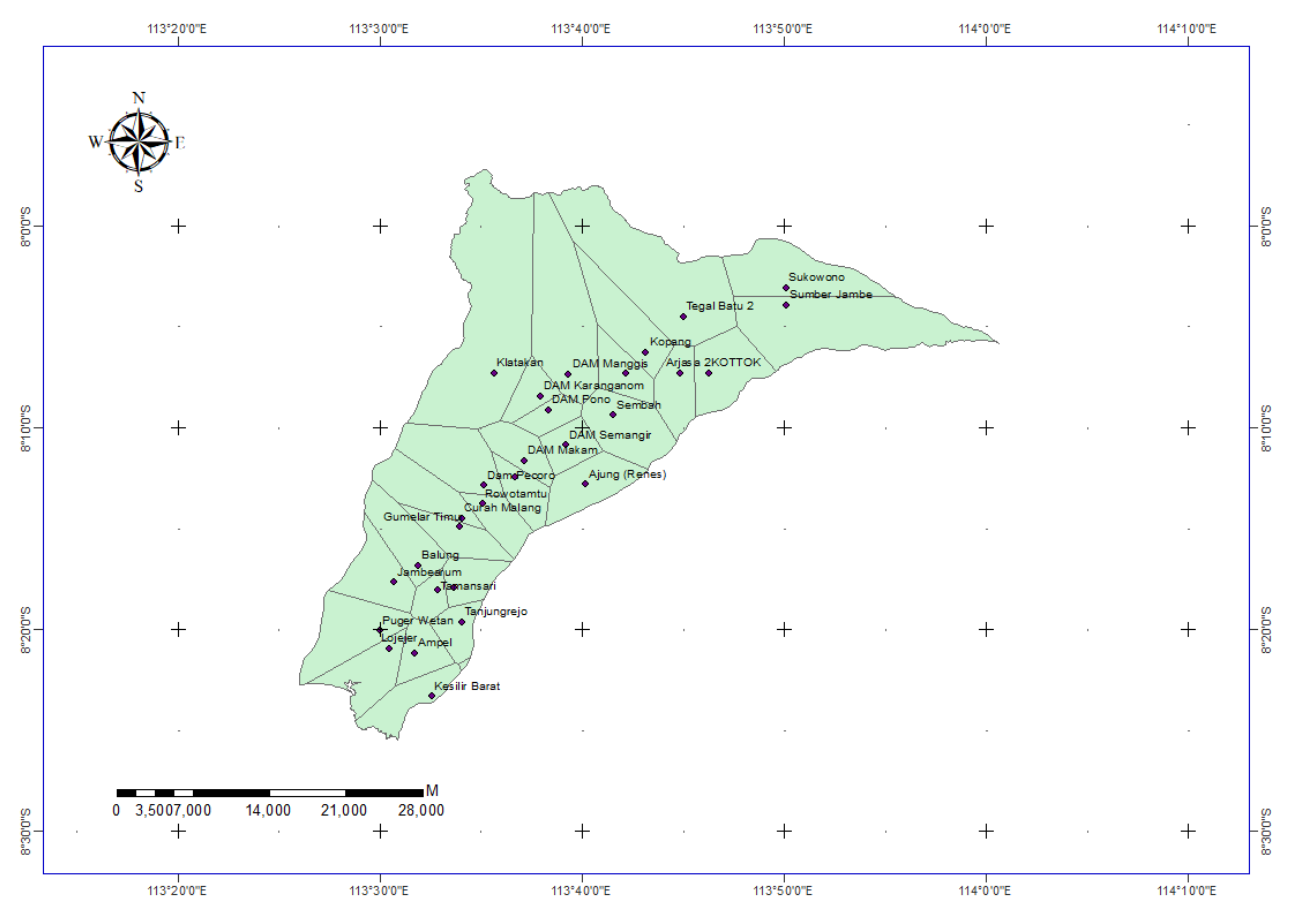

Gambar 1 Lokasi DAS dan titik stasiun hujan

Tahapan penelitian diawali dengan pengumpulan data yang dibutuhkan yaitu data yang didapat dari dinas terkait. Data yang telah terkumpul kemudian dilakukan pengolahan masing-masing data tersebut. Tahap setelah pengumpulan data yang pertama yaitu pengolahan data curah hujan menjadi data bulanan. Dalam data curah hujan, data yang tidak lengkap dihitung menggunakan metode Inverse Distance Weighting (IDW). Metode tersebut memperhitungkan jumlah debit dan panjang antar stasiun. Rumus metode Inversed Square Distance (IDW) merupakan persamaan yang membagi curah hujan di sekitar stasiun dalam periode yang sama dengan kuadrat jarak antar stasiun (Rizky dkk., 2019).

Tahap kedua yaitu pengujian kestabilan data dengan cara kurva massa ganda dan abnormalitas. Pengujian konsistensi massa ganda digunakan untuk mendapat keakuratan data apakah telah konsisten. Pembuatan grafik kurva massa ganda dengan nilai kumulatif curah hujan tahunan satu stasiun dan kumulatif curah hujan

Analisis Kekeringan Meteorologi Menggunakan Metode Standardized Preciptation Index (SPI) di Das Bedadung Kabupaten Jember - Citra Malini, Gusfan Halik, Retno Utami Agung Wiyono 
tahunan stasiun pembanding. Data yang diperoleh tidak terdapat perubahan atau kendala maka didapat garis linear, apabila pada suatu tahun terdapat perubahan maka didapat garisnya patah (Soemarto, 1987). Tahapan perhitungan uji abnormalitas dengan mengikuti urutan pada buku (Sosrodarsono, 1987) yaitu persamaan iwai. Hasil analisis jika $\varepsilon>\varepsilon_{0}$, maka nilai Xe (nilai maksimum atau minimum) tidak dapat disingkirkan dan data yang digunakan dapat dilanjutnya dalam penelitian. Apabila nilai $\varepsilon>\varepsilon_{0}$ tidak terpenuhi, perlu dilakukan perbaikan.

Tahap ketiga adalah perhitungan dengan memakai metode SPI. Metode SPI adalah indikator yang digunakan untuk menetukan curah hujan dan deviasi standar di jangka periode yang panjang. Metode SPI dikembangkan oleh (McKee dkk., 1993) yaitu model yang mengukur curah hujan yang tidak mencukupi dalam berbagai periode berdasarkan kondisi normal (Saidah dkk., 2017).

Menurut Bordi dkk (2009) dalam (Afdeni dkk., 2016) karean penggunaan data statistik yang konsisten, metode SPI banyak digunakan untuk menentukan tingkat kekeringan di berbagai wilayah iklim. Menurut (Anwar dkk., 2015) Defisit curah hujan akan mempengaruhi kelembaban tanah, kapasitas waduk, dan ketinggian permukaan air pada suatu periode. Faktor musiman pada seri data terdistribusi seri yang sama data curah hujan bulananan dihilangkan dengan cara data diubah. Pertama, datanya diubah menjadi fungsi distribusi kumulatif dengan menerapkan distribusi gamma. Fungsi itu kemudian diubah menjadi bentuk distribusi normal. Periode pengukuran SPI didasarkan pada skala waktu 1, 3, 6, 9, 12, dan 24 bulan. Fungsi distribusi frekuensi gamma seperti seperti persamaan (1):

$$
G(x)=x \int_{0}^{x} g(x) d x=\frac{1}{\beta^{\alpha} I(a)} \int_{0}^{x} t^{a-1} e^{\frac{-x}{\beta}} d x
$$

di mana

$$
\begin{aligned}
& \alpha=\frac{x^{2}}{S d^{2}} \\
& \beta=\frac{x}{\alpha}
\end{aligned}
$$

Dengan:

$$
A=\ln (\ddot{x})-\left(\frac{\sum \ln (x)}{n}\right)
$$

Fungsi gamma tidak didefinisikan untuk $\mathrm{x}=0$, nilai $\mathrm{G}(\mathrm{x})$ menjadi:

$$
H(x)=\mathrm{q}+(1-\mathrm{q}) \mathrm{G}(\mathrm{x})
$$

Nilai $\mathrm{q}=\mathrm{m} / \mathrm{n}$ dengan nilai $\mathrm{m}$ adalah banyaknya kejadian curah hujan $0 \mathrm{~mm}$ pada seri data curah hujan.

Perhitungan nilai SPI untuk $0<\mathrm{H}(\mathrm{x}) \leq 0,5$

$$
Z=S P I-\left(1-\frac{C o+C 1 t+C 2 t^{2}}{1+d 1 t+d 2 t^{2}+d 3 t^{3}}\right)
$$

Analisis Kekeringan Meteorologi Menggunakan Metode Standardized Preciptation Index (SPI) di Das Bedadung Kabupaten Jember - Citra Malini, Gusfan Halik, Retno Utami Agung Wiyono 
dan transform gamma distribution:

$$
t=\sqrt{\ln \left[\frac{1}{(H(x))^{2}}\right]}
$$

sedangkan untuk $0,5<\mathrm{H}(\mathrm{x}) \leq 1,0$

$$
Z=S P I+\left(1-\frac{C o+C 1 t+C 2 t^{2}}{1+d 1 t+d 2 t^{2}+d 3 t^{3}}\right)
$$

dan ubah distribusi gamma:

$$
t=\sqrt{\ln \left[\frac{1}{(1-H(x))^{2}}\right]}
$$

dengan:

$$
\begin{array}{ll}
\mathrm{C}_{0}=2.515517 & \mathrm{~d}_{1}=1.432788 \\
\mathrm{C}_{1}=0.802853 & \mathrm{~d}_{2}=0.189269 \\
\mathrm{C}_{2}=0.010328 & \mathrm{~d}_{3}=0.001308
\end{array}
$$

Ketika nilai SPI bernilai negatif dan mencapai intensitas kekeringan -1 atau kurang, akan terjadi kekeringan. Dalam Tabel 1 dijelaskan klasifikasi nilai SPI.

Tabel 1 Nilai klasifikasi SPI

\begin{tabular}{cc}
\hline Nilai SPI & Klasifikasi \\
\hline$\geq 2,00$ & Amat sangat basah \\
\hline 1,50 s.d 1,99 & Sangat basah \\
\hline 1,00 s.d 1,49 & Cukup basah \\
\hline$-0,99$ s.d 0,99 & Mendekati normal \\
\hline$-1,00$ s.d $-1,49$ & Cukup kering \\
\hline$-1,50$ s.d $-1,99$ & Sangat kering \\
\hline$\leq-2,00$ & Amat sangat kering \\
\hline
\end{tabular}

Tahap keempat, pemetaan spasial Sistem Informasi Geografis (SIG) merupakan alat sistem komputer yang dapat menganalisis, merekam, menyimpan, dan menampilkan data geografis (Sasmito, 2017). Keunggulan dari SIG adalah dapat memberikan informasi yang mendekati kondisi sebenarnya, memprediksi hasil dan melakukan perencanaa stategis. SIG mengintegrasikan lima komponen yaitu: data, perangkat lunak (software), perangkat keras (hardware), pengguna (user), dan aplikasi (Masykur, 2014).

\section{Hasil dan Pembahasan}

\subsection{Data Curah Hujan Yang Hilang}

Data curah hujan yang dihitung dalam stasiun hujan tidak selalu lengkap dikarenakan beberapa kendala seperti terjadinya alat rusak atau kurangnya SDM dalam mencatat data hujan dari alat. Data hilang dihitung dengan menggunakan

Analisis Kekeringan Meteorologi Menggunakan Metode Standardized Preciptation Index (SPI) di Das Bedadung Kabupaten Jember - Citra Malini, Gusfan Halik, Retno Utami Agung Wiyono 
metode inversed square distance untuk meningkatkan kualitas data dalam penelitian. Metode inversed square distance membandingkan curah hujan dengan jarak antar stasiun hujan terdekat.

\subsection{Uji Konsistensi Massa Ganda}

Uji konsistensi digunakan untuk mengecek kualitas data, pada penelitian ini digunakan metode kurva massa ganda. Data yang akan diuji adalah nilai perhitungan data curah hujan kumulatif tiap stasiun dan kumulaif rerata data curah hujan stasiun pembanding. Hasil yang didapat dari uji konsistensi nilai regresi $\left(\mathrm{R}^{2}\right)$ dan grafik linier, penelitian dapat dilakukan dengan data tersebut.

Hasil uji konsistensi data hujan observasi DAS Bedadung periode 1990-2019 pada 30 stasiun hujan diperoleh nilai $\mathrm{R}^{2} \approx 1$. Nilai tersebut membuktikan bahwa data hujan observasi merupakan data yang konsisten.

\subsection{Uji Abnormalitas}

Uji abnormalitas digunakan untuk mengetahui kelayakan data curah hujan yang digunakan. Data yang digunakan merupakan data terbesar dan terkecil dalam rangkaian data yang ada. Hasil analisis harga maksimum diperoleh nilai $\varepsilon=0,1357$ dan $\varepsilon_{0}=0,0018$. Hasil analisis harga minimum diperoleh nilai $\varepsilon=0,1742$ dan nilai $\varepsilon_{0}=0,0017$. Harga maksimum sebesar 0,1357 >0,0018 dan harga minimum sebesar $0,1742>0,0017$.

Hasil $\varepsilon>\varepsilon_{0}$, maka nilai Xe (nilai maksimum atau minimum) tidak dapat disingkirkan. Sehingga data curah hujan dapat dilanjutkan dalam penelitian. Apabila nilai $\varepsilon>\varepsilon_{0}$ tidak terpenuhi, perlu dilakukan koreksi. Dalam koreksi, menghasilkan faktor koreksi yang akan digunakan uji konsistensi pada stasiun hujan.

\subsection{Perhitungan SPI}

Data curah hujan yang telah diuji konsistensi dan abnormalitasnya menunjukkan bahwa data yang digunakan layak dan dapat digunakan untuk penelitian selanjutnya. Data yang telah dinyatakan layak, data curah hujan dilakukan perhitungan metode SPI dengan persamaan (1) sampai persamaan (8).

Hasil dari perhitungan SPI ini yang mengalami kekeringan ekstrim hingga membutuhkan pasokan air adalah pada tahun 2018 dan 2019. Pemilihan SPI-6 dikarenakan lebih sesuai dengan di lapangan dan jika nilai SPI-3 kebawah digunakan untuk menganalisis kekeringan dasar.

Dari hasil analisis indeks kekeringan SPI-6 yang didapat pada stasiun Ajung mengalami kekeringan ekstrim yaitu -2.69. Kondisi ini masuk dalam klasifikasi sangat kering karena berada di bawah nilai -2 . Semua nilai indeks kekeringan dilakukan analisis melalui grafik untuk mempermudah mengetahui kapan dan durasi kekeringan yang terjadi menurut data hujan selama 3 tahun.

Nilai indeks SPI yang telah dibuat grafik (Gambar 2.) mempermudah melihat waktu bulan yang mengalami bulan kering atau basah beserta durasinya. Dari data SPI didapat bulan November tahun 2019 yang mengalami kekeringan dengan

Analisis Kekeringan Meteorologi Menggunakan Metode Standardized Preciptation Index (SPI) di Das Bedadung Kabupaten Jember - Citra Malini, Gusfan Halik, Retno Utami Agung Wiyono 
diperoleh SPI-3 diperoleh 3.04, SPI-6 diperoleh -2.69 dan SPI-9 diperoleh -2.94. Hasil indeks SPI di stasiun Ajung dari SPI-1 dalam klasifikasi bulan sangat kering dan hasil SPI-3,6, dan 9 dalam klasifikasi amat sangat kering. Hasil dalam perhitungan SPI dengan defisit curah hujan untuk 3, 6 dan 9 dinyatakan wilayah dari stasiun Ajung mengalami kekeringan dan diperkuat dengan data distribusi air bersih yang dibutuhkan masyarakat. Menjadi salah satu wilayah yang mengalami dampak kekeringan, daerah lokasi stasiun Ajung membutuhan ditribusi air bersih yang tercatat di data BPBD mencapai 115.000 liter. Dari data permintaan pendistribusian, sebanyak 591 kepala keluarga yang membutuhkan air bersih. Distribusi air yang begitu banyak hanya untuk kebutuhan memasak dan mandi belum untuk kegiatan pertanian dan lain sebagainya.

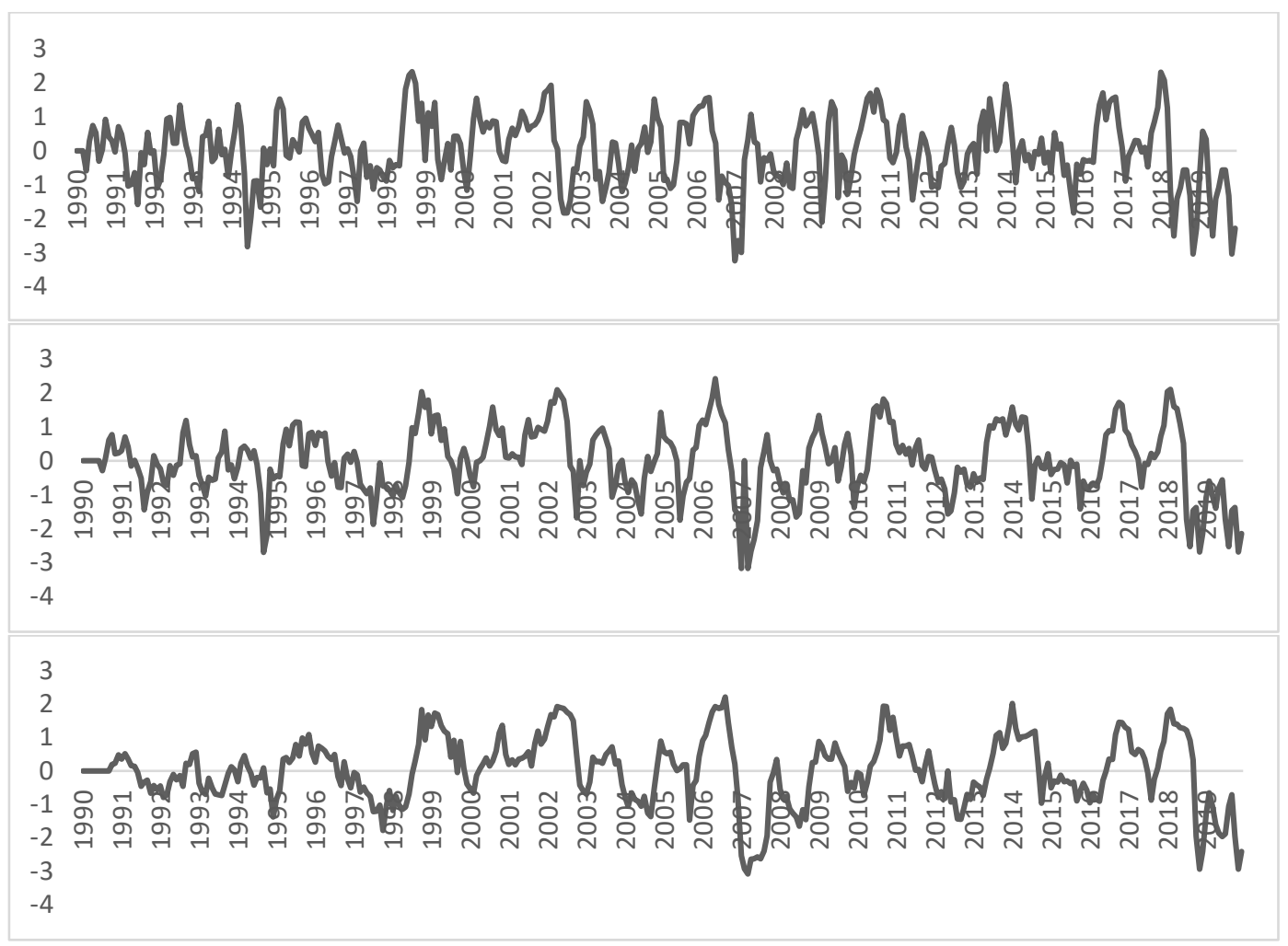

Gambar 2 Grafik SPI Stasiun Ajung

\subsection{Pemetaan dan Validasi Sebaran Kekeringan}

Pemetaan daerah kekeringan dengan menggunakan interpolasi IDW. Untuk data yang dipetakan berdasarkan nilai perhitungan SPI yaitu yang mengalami kekeringan ekstrim pada bulan November 2019. Pemetaan didapat jangkauan wilayah yang terdampak dengan besar indeks kekeringan di setiap stasiun curah hujan pada gambar 3 .

Luas wilayah kekeringan DAS Bedadung dari distribusi air BPBD di setiap desa total ada $753,49 \mathrm{~km}^{2}$. Daerah kekeringan yang membutuhkan distribusi air yaitu $66,96 \%$ dari total luas DAS. Daerah yang mengalami kekeringan ekstrim lebih dari setengah total luas DAS yang dapat diartikan bahwa curah hujan di DAS

Analisis Kekeringan Meteorologi Menggunakan Metode Standardized Preciptation Index (SPI) di Das Bedadung Kabupaten Jember - Citra Malini, Gusfan Halik, Retno Utami Agung Wiyono 
Bedadung pada bulan November 2019 dibawah normal. Hasil validasi peta kesesuaiannya sebesar kurang lebih $82 \%$.

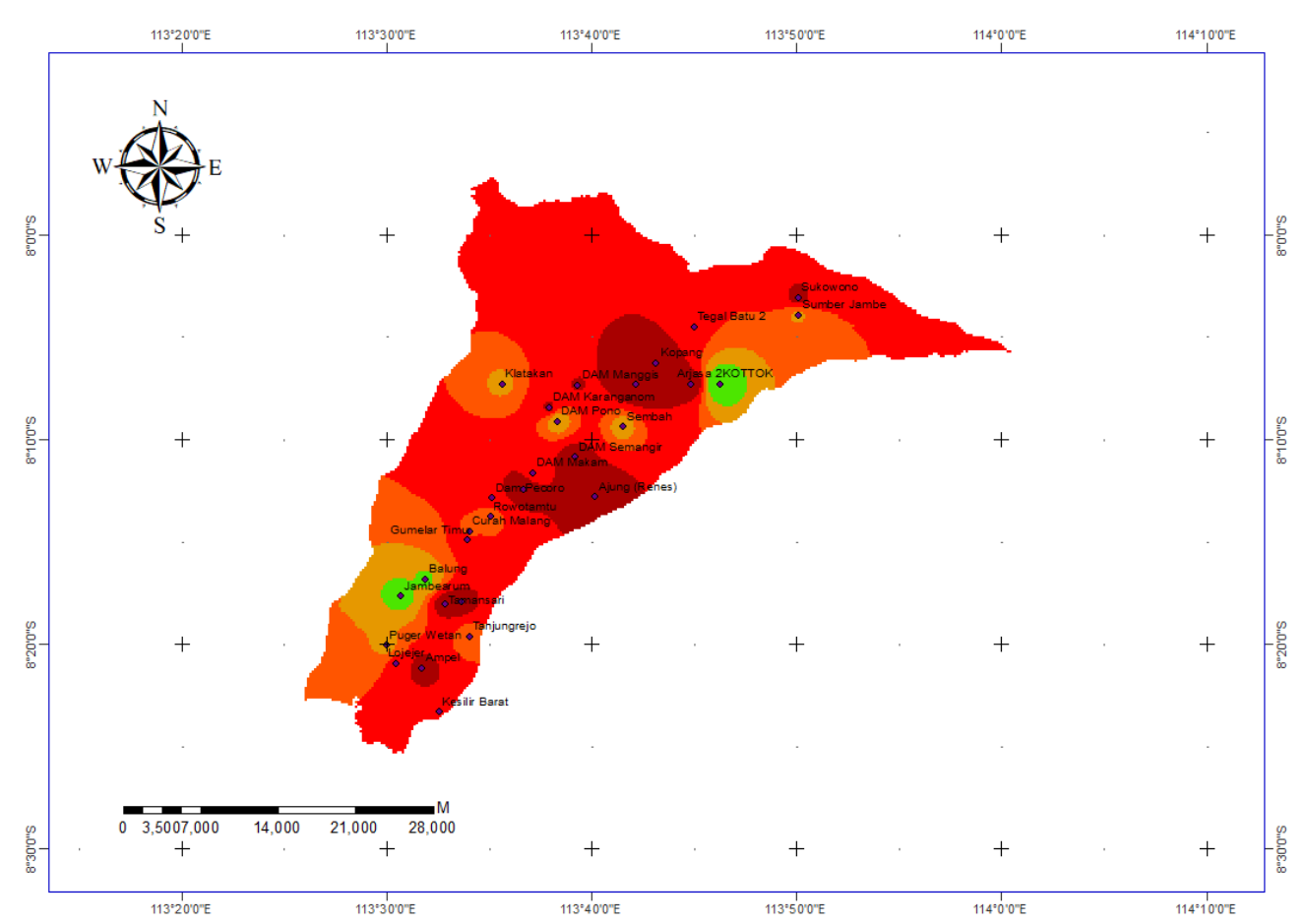

Gambar 3 Peta Sebaran Kekeringan 2019

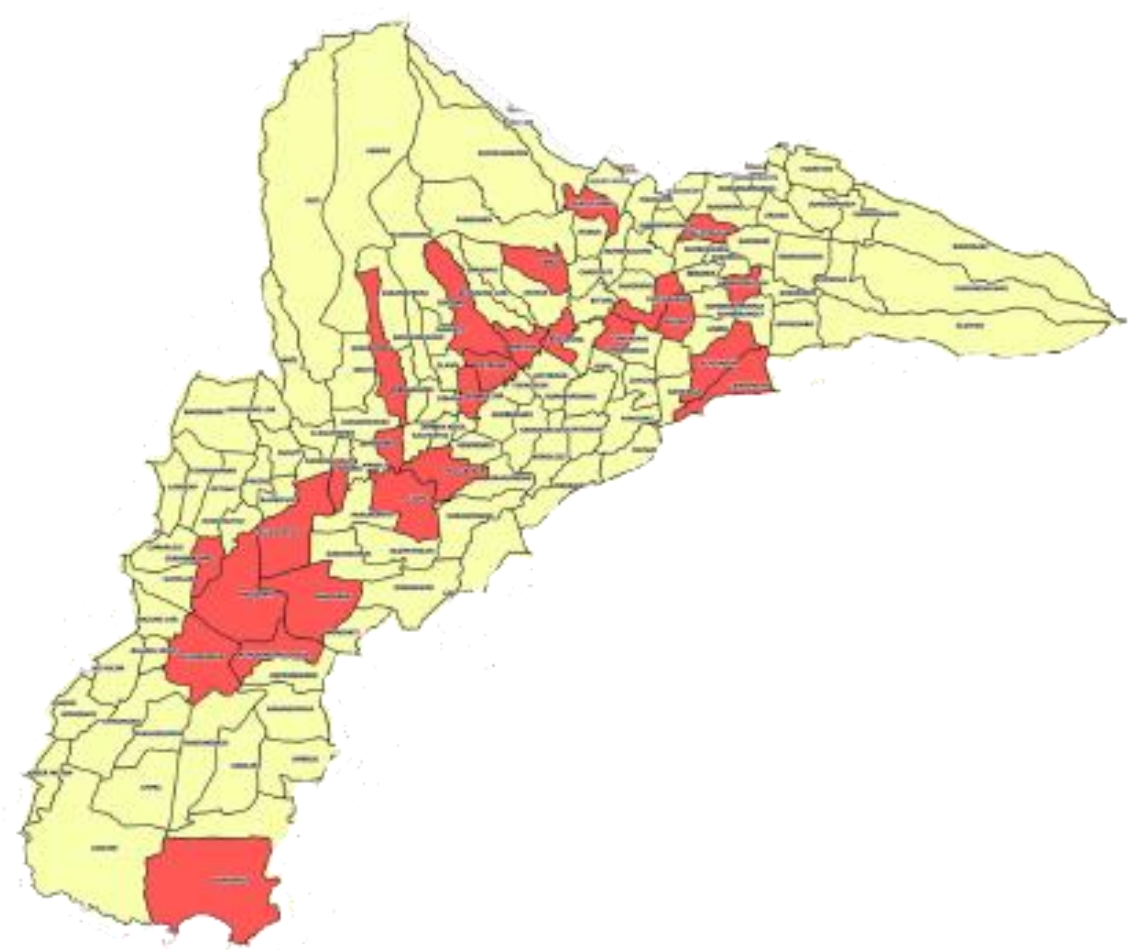

Gambar 4 Peta Distribusi Air Bersih BPBD

Analisis Kekeringan Meteorologi Menggunakan Metode Standardized Preciptation Index (SPI) di Das Bedadung Kabupaten Jember - Citra Malini, Gusfan Halik, Retno Utami Agung Wiyono 


\section{Kesimpulan dan Saran}

\subsection{Kesimpulan}

Berdasarkan analisis indeks kekeringan dengan SPI di DAS Bedadung maka dapat dinyatakan bahwa bencana kekeringan ekstrim pada bulan November tahun 2019. Indeks kekeringan yang terjadi di stasiun Ajung dengan SPI-3 diperoleh nilai -3.04, SPI-6 diperoleh -2.69 dan SPI-9 diperoleh -2.94. Hasil pemetaan spasial indeks SPI terdapat 54,28\% dari total luas DAS mengalami kekeringan ekstrim. Kesesuaian hasil pemetaan spasial kekeringan SPI terhadap data dropping air dari BPBD sebesar 82\%. Berdasarkan hasil kesesuaian pemetaan, maka dapat dinyatakan bahwa SPI-6 dapat digunakan untuk memonitor bencana kekeringan di DAS Bedadung Kabupaten Jember.

\subsection{Saran}

Berdasarkan hasil penelitian ini dapat disarankan untuk melakukan analisis indeks kekeringan dengan menggunakan metode yang berbeda seperti indeks kekeringan secara hidrologi.

\section{Daftar Kepustakaan}

Adnyana, W.S., I. W. Nuarsa, dan A. Rahman, 2015. Pemetaan Daerah Rawan Kekeringan di Bali-Nusa Tenggara Dan Hubungan Dengan Enso Menggunakan Aplikasi Data Penginderaan Jauh. Jurnal Bumi Lestari, 15(1): 20-30.

Afdeni, S., Y. L. Handayani, dan Sutikno, 2016. Analisis Indeks Kekeringan Meteorologis Lahan Gambut Di Pulau Bengkalis, Jom Fteknik, 4(2): 1-10.

Anwar, N., G. Halik, dan Edijanto. 2015. Statistical Downscaling Model for Assessing Drought Disaster Due to Climate Change at Sampean Watershead, Indonesia. $22^{\text {nd }}$ International Congress on Irrigation and Drainage. Vol 1: 112.

Faisol, A., Budiyono, Indarto, dan E. Novita, 2020. Pemanfaatan Data Global Precipitation Measurement (GPM) dan Standardized Precipitation Index (SPI) untuk Deteksi Kekeringan Meteorologis di Provinsi Papua Barat. Jurnal teknologi Pertanian. 13(1): 8-15.

Halik, G., B. Santosa, dan N. Anwar, 2015. Reservoir Inflow Prediction under GCM Scenario Downscaled by Wavelet Transform and Support Vector Machine Hybrid Models. Advance in Civil Engineering, 9 pages.

Kurniawan, A.R.., M. Bisri, dan Suhartanto, 2019. Analisis Kekeringan Pada Daerah Aliran Sungai (DAS) Bedadung Berbasis Sistem Infromasi Geografis (SIG), Jurnal Teknik Pengairan, 10(2): 97-109.

Masykur, F, 2014. Implementasi Sistem Informasi Geografis Menggunakan Goggle Maps API dalam Pemetaan Asal Mahasiswa. Jurnal SIMETRIS. 5(2): 181186.

Analisis Kekeringan Meteorologi Menggunakan Metode Standardized Preciptation Index (SPI) di Das Bedadung Kabupaten Jember - Citra Malini, Gusfan Halik, Retno Utami Agung Wiyono 
McKee, T.B., N. J. Doesken, dan J. Kleist, 1993. The relationship of drought frequency and duration to time scale. Proceddings of the Eighth Conference on Applied Climatology. 17-22 Januari 1993. Boston, American Meteorological Society: 179-184.

Rizky, H., Y. N. Nasution, dan R. Goejantoro, 2019. Analisis Data Curah Hujan Yang Hilang Menggunakan Metode Inversed Square Distance. Prosiding Seminar Nasional Matematika, Statistika, dan Aplikasi. 5 Oktober 2019, Samarinda, Indonesia: 138-142.

Saidah, H., M. B. Budianto, dan L. Hanifa, 2017. Analisa Indeks Dan Sebaran Kekeringan Menggunakan Metode Standardized Precipitation Index (SPI) dan Geographical Informmation System (GIS) Untuk Pulau Lombok. Jurnal Spektran. 5(2): 173-179.

Soemarto, CD, 1987. Hidrologi Teknik. Surabaya, Usaha Nasional

Sasmito, G.W, 2017. Penerapan Metode Rainfall Pada Desain Sistem Infromasi Geografis Industri Kabupaten Tegal. Jurnal Pengembangan IT (JPIT), 2(1): 6-12.

Sosrodarsono, S, 1987. Hidrologi Untuk Pengairan. Jakarta, Pradnya Paramita

Sudarman, I. M. dan A. R. As-Syakur, 2018. Dampak Perubahan Iklim Terhadap Sektor Pertanian di Provinsi Bali. SOCA, Jurnal Sosial Ekonomi Pertanian, 12(1): 87.

Utami, D., R. Hadiani, dan Susilowati, 2013. Prediksi Kekeringan Berdasarkan Standardized Precipitation Index (SPI) Pada Daerah Aliran Sungai Keduang di Kabupaten Wonogiri. Matriks Teknik Sipil: 221-226. 